\title{
Workplace Access to Journals: Is it Sufficient to Support Quality Healthcare Practice in Medical Imaging Workers?
}

Madeleine C. Shanahan

RMIT University, School of Medical Sciences, madeleine.shanahan@rmit.edu.au

Follow this and additional works at: https://nsuworks.nova.edu/ijahsp

Part of the Radiology Commons

\section{Recommended Citation}

Shanahan MC. Workplace Access to Journals: Is it Sufficient to Support Quality Healthcare Practice in Medical Imaging Workers?. The Internet Journal of Allied Health Sciences and Practice. 2016 Jan 01;14(1), Article 8.

This Manuscript is brought to you for free and open access by the College of Health Care Sciences at NSUWorks. It has been accepted for inclusion in Internet Journal of Allied Health Sciences and Practice by an authorized editor of NSUWorks. For more information, please contact nsuworks@nova.edu. 


\title{
Workplace Access to Journals: Is it Sufficient to Support Quality Healthcare Practice in Medical Imaging Workers?
}

\begin{abstract}
Introduction: Journals are important tools for disseminating new knowledge to health professionals. The purpose of this study was to investigate workplace access to journals. Medical imaging workers (MIWs) were the allied health professional group studied. Methods: A two phase sequential exploratory mixed methods design was adopted to collect data from MIWs to develop a list of professionally relevant journals and to examine accessibility of journals across the profession. In addition, the derived list of journals was further examined to determine open access and open article availability. Results: Twentyseven percent $(n=88)$ of survey respondents $(N=362)$ reported that they have access to one $(18 \%, n=58)$ or none $(9 \%, n=30)$ of the 94 identified professionally relevant journals. Difference in access was statistically significant for work setting (university, clinical), health sector (public, private), workplace type (teaching, non-teaching hospital, clinic), and area of specialization (nuclear medicine, radiation therapy, radiography, sonography). A positive relationship was shown to exist between increased effective workplace access to journals and frequency of use. This study also identified that open access journals and articles are currently limited for Medical Imaging workers. Conclusion: Whilst journals provide access to current peerreviewed evidence, this study established that workplace access is currently problematic for medical imaging workers. Workplaces must act to increase access to journals for Medical Imaging Workers so that these professionals can harness new knowledge and base their practice on current peer-reviewed evidence.
\end{abstract}

\begin{abstract}
Author Bio(s)
Madeleine Shanahan, PhD, is a Senior Lecturer at the RMIT University, School of Medical Sciences in Australia. Madeleine's research has two broad foci. One area of interest is learning mediated by knowledgetools with research conducted at the undergraduate and graduate Medical Imaging Worker (MIW) level. This research has employed quantitative and qualitative research methodologies. A second research focus examines technologies in medical imaging, where experimental design has been adopted.
\end{abstract}




\title{
TIJAHSP \\ The Internet Joưnal of Allied Health Sciences and Practice
}

Dedicated to allied health professional practice and education

Vol. 14 No. 1 ISSN 1540-580X

\section{Workplace Access to Journals: Is it Sufficient to Support Quality Healthcare Practice in Medical Imaging Workers?}

\author{
Madeleine Shanahan, PhD, MAppSc, BEd, FIR
}

RMIT University, School of Medical Sciences

Australia

\begin{abstract}
Introduction: Journals are important tools for disseminating new knowledge to health professionals. The purpose of this study was to investigate workplace access to journals. Medical imaging workers (MIWs) were the allied health professional group studied. Methods: A two phase sequential exploratory mixed methods design was adopted to collect data from MIWs to develop a list of professionally relevant journals and to examine accessibility of journals across the profession. In addition, the derived list of journals was further examined to determine open access and open article availability. Results: Twenty-seven percent ( $n=88$ ) of survey respondents $(\mathrm{N}=362)$ reported that they have access to one $(18 \%, \mathrm{n}=58)$ or none $(9 \%, \mathrm{n}=30)$ of the 94 identified professionally relevant journals. Difference in access was statistically significant for work setting (university, clinical), health sector (public, private), workplace type (teaching, non-teaching hospital, clinic), and area of specialization (nuclear medicine, radiation therapy, radiography, sonography). A positive relationship was shown to exist between increased effective workplace access to journals and frequency of use. This study also identified that open access journals and articles are currently limited for Medical Imaging workers. Conclusion: Whilst journals provide access to current peer-reviewed evidence, this study established that workplace access is currently problematic for medical imaging workers. Workplaces must act to increase access to journals for Medical Imaging Workers so that these professionals can harness new knowledge and base their practice on current peerreviewed evidence.
\end{abstract}

\section{INTRODUCTION}

Rapidly evolving technology, advances in diagnosis and treatment, and increased role responsibilities are constant forces impacting on health professionals' knowledge and practice. ${ }^{1}$ Healthcare standards set by government and professional bodies emphasise the importance of individuals maintaining currency of their professional knowledge. For example, the Health and Care Professions Council, United Kingdom, states that keeping skills and knowledge up to date is essential for safe and effective work practice. ${ }^{2}$ The Australian CareTrack study compared healthcare delivered to patients against evidence-based or consensus guidelines and established that $43 \%$ of healthcare practice was not in accord with the latest standards. ${ }^{3}$ This suggests that a large number of health professionals base clinical practice decisions on professional knowledge that may no longer be current.

Journals are recognised as important tools for disseminating new knowledge supporting health professionals to base their clinical practice on current health information. 4,5 For example, in a recent study examining evidence-based practice of Australian allied health professionals, $65 \%$ of respondents reported they read published research at least monthly. ${ }^{6}$ Despite the recognised importance of journals in supporting best-practice healthcare, access to journals in the workplace may be problematic for many health professionals. ${ }^{6-8}$ Lack of access to information/evidence was identified by Melnyk et al as a barrier preventing nurses from implementing evidence-based practice. ${ }^{8}$ When respondents in the Melnyk et al study were asked "What is the "one thing" that would help you implement EBP in your daily practice?, ,p.p.414 "access to information" was the second highest response (n=100), behind education $(n=114)$. As journals are an important tool for disseminating new evidence, it is important to understand factors that influence their access in the workplace. ${ }^{4}$ Health sector (public, private), work setting and workplace type (university, teaching or non-teaching hospital), and area of specialization of the health professional have been identified as influencing workplace access to journals. ${ }^{4,6,7}$ However, these studies are over ten years old and accessibility of journals may now have changed. For instance, according to the Directory of Open Access Journals, there are currently 10,093 open access journals. ${ }^{10}$ Many

(c) The Internet Journal of Allied Health Sciences and Practice, 2016 
subscription-based journals also publish open access articles. What is not known is how widespread this facility is for journals that are relevant to a given health profession. There is a need for further research to establish factors that currently influence health professionals' workplace access to journals and determine what journals are open access or have open access articles.

Professions have distinctive knowledge bases and so information sources, such as journals, are specific to the occupational group. This is apparent as core journals have been identified for many health professions., ${ }^{4,11-16}$ The occupational group studied was Australian medical imaging workers (MIWs), which includes radiographers, radiation therapists, nuclear medicine technologists and sonographers. ${ }^{17}$ This paper examined the following research questions:

1. How accessible are professional relevant journals to MIWs in their workplace?

2. Does workplace accessibility to journals influence frequency of use in MIWs?

\section{METHOD}

This study adopted a two-phase sequential exploratory mixed methods design. Qualitative data (Phase 1) were collected, analysed, and then used to explicitly inform the quantitative phase (Phase 2). ${ }^{18,19}$ This design is typically adopted when a survey instrument needs to be developed, ${ }^{19}$ in this study to account for the contextually bound journals of the specialist health professionals of focus. ${ }^{6,19}$

Phase 1 involved semi-structures interviews with $28 \mathrm{MIWs}$. Stratified purposeful sampling was used to include participants from sub-groups of interest, namely expert knowledge (14 academic and 14 senior/ management clinical practitioners) and area of specialization (7 nuclear medicine, 7 radiation therapy, 8 radiography and 6 sonography). ${ }^{20}$ Phase 1 sought to establish what journals are utilised by MIWs to update their professional knowledge. The findings from Phase 1 informed Phase 2, which involved the development and administration of a questionnaire to Australian MIWs. The questionnaire was pilot tested, with seven additional senior MIWs before it was administered. Responses indicated that the instrument had a clear layout and the questions were clearly written and easily understood. This approach also provided another opportunity to enhance content coverage of the instrument, with five more journal titles added to the final questionnaire. The sample population for Phase 2 of the study was Australian MIWs holding registration with the medical radiation practitioner board. Random sampling was used to obtain the survey sample ( $\mathrm{N}=1142)$. Due to funding constraints, only one mail-out was undertaken. Prior to data collection the research gained ethics approval from the University of Wollongong, Australia.

Survey data were entered into IBM ${ }^{\circledR}$ SPSS ${ }^{\circledR} 22.0$ and descriptive and inferential statistics used for analysis. Descriptive statistics were generated to ascertain the number and percent of MIWs that use journals to update their professional knowledge. Workplace access to journals was determined using two measures -physical access (number of journals MIWs report that they could access from the provided list of 94 journal titles), and ease of access, which measures an individual's effective access in practice. ${ }^{21}$ After testing for assumption of equal variance, the test of difference (parametric or non-parametric) for physical access was determined by the number of sub-groups within the tested independent variables. ${ }^{20,22}$ In relation to effective access to journals in the workplace, respondents were asked to rate their access to print and electronic journals using a five point scale from 1 very easy to 5 not easy. Respondents could also identify that they had no access to journals. Cross tabulation was performed to determine factors influencing workplace ease of access to journals and if ease of access was associated with selfreported frequency of journal use using chi-square and Fisher's exact test, when expected cell frequencies were below five. ${ }^{22}$

Further analysis of the generated list of journals was undertaken to identify which, if any, were available as open access or had open access articles by searching the Directory of Open Access Journals (http://doaj.org/ accessed 1 December, 2014) and SHERPA/RoMEO (http://www.sherpa.ac.uk/romeo/search.php accessed 2 December, 2014) databases. In addition, for a subset of five journals, the number of open access articles for the period 2013-2014 was determined by using Science Direct (http://www.sciencedirect.com/science/jrnlallbooks/all-open-access/a accessed 9 December, 2014) to access the journal, then sum the number of open access and full text articles and total number of original research papers, technical notes, review articles, and clinical guidelines for each issue of the journal within the nominated time period.

\section{RESULTS}

The response rate for the survey was $31.7 \%(\mathrm{~N}=362)$ of all MIWs sampled. A summary of key demographic characteristics of survey respondents is presented in Table 1. The distribution for area of specialization and gender was similar to available national data suggesting that the demographic profile of the respondents is representative of the broader Australian population of MIWs. ${ }^{17}$ 
Table 1. Demographic Characteristics of Survey Participants ( $N=362$ )

\begin{tabular}{|l|l|c|}
\hline \multicolumn{2}{|l|}{ Characteristic } & No. (Valid Percent) \\
\hline Area of Specialization & Ruclear Medicine & $43(11.9)$ \\
& Radiation therapy & $77(21.3)$ \\
& Radiography & $184(50.8)$ \\
& Sonography & $58(16.0)$ \\
\hline Geographic Location & Metropolitan & $208(58.3)$ \\
& Regional & $95(26.6)$ \\
& Rural and remote & $54(15.1)$ \\
\hline Primary Role & Practitioner & $151(43.1)$ \\
& Senior Practitioner & $84(24.0)$ \\
& Manager & $57(16.3)$ \\
& Clinical Educator & $19(5.4)$ \\
& Academic & $28(8.0)$ \\
& Other & $11(3.0)$ \\
\hline Gender & Female & $246(68.5)$ \\
& Male & $113(31.5)$ \\
\hline Years of Professional Experience & $<5$ years & $64(17.7)$ \\
& $5-10$ years & $64(17.1)$ \\
& $11-15$ years & $51(14.1)$ \\
& $>15$ years & $183(50.6)$ \\
\hline Health Sector ${ }^{b}$ & Public & $169(53.1)$ \\
& Private & $149(46.9)$ \\
\hline Work Environment ${ }^{b}$ & Teaching hospital & $173(55.4)$ \\
& Non-teaching hospital & $46(14.7)$ \\
& Clinic & $93(29.8)$ \\
\hline a Percentages are based upon number of respondents answering each question. \\
b The responses to these organisation factors are limited to clinical practitioners (N=320) and exclude those who \\
indicated they worked in more than one type of these environments or who selected "other" \\
\hline
\end{tabular}

1. How accessible are professional relevant journals to MIWs in their workplace?

Table 2 displays the specific titles (former title in brackets) read by MIWs (Column 2, Phase 1 interview data). MIWs report that they read a broad range of journals to update their professional knowledge including discipline-specific journals for nuclear medicine, radiation therapy, radiography and sonography as well as broad categories of medicine, education, oncology and physics. Journal titles in bold were previously identified as core journals. ${ }^{12-16}$

The number of MIWs who report having access to each of the listed journal titles is presented in Table 2, Column 3 . The majority of respondents $(91 \%, n=295)$ indicated that they had access to one $(18 \%, n=58)$ or more $(73 \%, n=237)$ of the listed journals. The median number of journals respondents could access was four $(I Q R=11)$. Nine percent of respondents $(n=30)$ reported they had access to none of the journals listed. 
Table 2. List of Professionally Relevant Journals and their Accessibility to MIWs

\begin{tabular}{|c|c|c|c|c|}
\hline $\begin{array}{ll} & \text { Data Source } \\
\text { Journal Title (previous title) } & \\
\end{array}$ & $\begin{array}{l}\text { Number who } \\
\text { read journal } \\
\\
\text { Phase } 1 \\
\text { Interview } \\
(\mathrm{N}=28)\end{array}$ & $\begin{array}{l}\text { Number } \\
\text { who have } \\
\text { access } \\
\\
\text { Phase } 2 \\
\text { Survey } \\
(\mathrm{n}=227)\end{array}$ & $\begin{array}{l}\text { Journal } \\
\text { is listed } \\
\text { as Open } \\
\text { Access } \\
\text { DOAJ }\end{array}$ & $\begin{array}{c}\text { Paid Open } \\
\text { Access } \\
\text { Available } \\
\text { (Author } \\
\text { pays per } \\
\text { article) } \\
\text { SHERPA/ } \\
\text { RoMEO }\end{array}$ \\
\hline Academic Radiology & 1 & 43 & $\mathrm{~N}$ & $\mathrm{Y}$ \\
\hline Acta Radiologica (Acta Radiologica. Diagnosis) & 1 & 42 & $\mathrm{~N}$ & $\mathrm{Y}$ \\
\hline American Journal of Hematology & 1 & 26 & $\mathrm{~N}$ & Y \\
\hline American Journal of Neuroradiology $a b$ & & 37 & $\mathrm{~N}$ & $\mathrm{Y}$ \\
\hline American Journal of Obstetrics \& Gynecology ${ }^{d}$ & & 40 & $\mathrm{~N}$ & $\mathrm{Y}$ \\
\hline American Journal of Roentgenology abd & 5 & 92 & $\mathrm{~N}$ & NS \\
\hline Applied Radiology ${ }^{c}$ & & 41 & $\mathrm{~N}$ & NS \\
\hline Australian Journal of Rural Health & 1 & 24 & $\mathrm{~N}$ & $\mathrm{Y}$ \\
\hline Australasian Journal of Ultrasound Medicine (Ultrasound Bulletin) & 4 & 42 & $\mathrm{~N}$ & $\mathrm{NL}$ \\
\hline Australasian Physical \& Engineering Sciences in Medicine & 1 & 34 & $\mathrm{~N}$ & $\mathrm{Y}$ \\
\hline Biomedical Imaging and Intervention Journal & 1 & 20 & $\mathrm{Y}$ & - \\
\hline Blood & 1 & 29 & $\mathrm{~N}$ & $\mathrm{Y}$ \\
\hline Brain: a journal of neurology & 1 & 22 & $\mathrm{~N}$ & $\mathrm{Y}$ \\
\hline Breast & 1 & 39 & $\mathrm{~N}$ & Y \\
\hline Breast Journal 9 & & 36 & $\mathrm{~N}$ & $\mathrm{Y}$ \\
\hline British Journal of Cancer $f$ & & 50 & $\mathrm{~N}$ & Y \\
\hline British Journal of Haematology & 1 & 29 & $\mathrm{~N}$ & $Y$ \\
\hline British Journal of Radiology bd & 5 & 85 & $\mathrm{~N}$ & $Y$ \\
\hline British Medical Journal (BMJ) & 1 & 79 & $\mathrm{~N}$ & $Y$ \\
\hline Cancer ad & & 53 & $\mathrm{~N}$ & $\mathrm{Y}$ \\
\hline Cancer Treatment Reviews & 1 & 33 & $\mathrm{~N}$ & Y \\
\hline Clinical Nuclear Medicine & 2 & 45 & $\mathrm{~N}$ & $\mathrm{~N}$ \\
\hline Clinical Oncology & 1 & 59 & $\mathrm{~N}$ & $Y$ \\
\hline Clinical Radiology $b$ & 1 & 77 & $\mathrm{~N}$ & $Y$ \\
\hline Cognition & 1 & 14 & $\mathrm{~N}$ & $\mathrm{Y}$ \\
\hline Diagnostic Imaging & 1 & 50 & $\mathrm{~N}$ & $\mathrm{NL}$ \\
\hline European Heart Journal & 1 & 24 & $\mathrm{~N}$ & $\mathrm{Y}$ \\
\hline European Journal of Cancer & 1 & 37 & $\mathrm{~N}$ & $\mathrm{Y}$ \\
\hline European Journal of Nuclear Medicine \& Molecular Imaging & 6 & 31 & $\mathrm{~N}$ & Y \\
\hline Gamma Gazette (ANZ Nuclear Medicine) & 5 & 57 & $\mathrm{~N}$ & $\mathrm{NL}$ \\
\hline Health Physics ${ }^{f}$ & & 36 & $\mathrm{~N}$ & $\mathrm{~N}$ \\
\hline Heart d & 1 & 26 & $\mathrm{~N}$ & $\mathrm{Y}$ \\
\hline IEEE Transactions on Medical Imaging & 1 & 17 & $\mathrm{~N}$ & $\mathrm{Y}$ \\
\hline International Journal of Radiation Oncology Biology -Physics ${ }^{a}$ & 7 & 54 & $\mathrm{~N}$ & $\mathrm{Y}$ \\
\hline Investigative Radiology ${ }^{b}$ & & 30 & $\mathrm{~N}$ & $\mathrm{~N}$ \\
\hline Journal of the American College of Cardiology de & 1 & 26 & $\mathrm{~N}$ & $\mathrm{Y}$ \\
\hline Joumal of the American Society of Echocardiography c & 3 & 24 & $\mathrm{~N}$ & $Y$ \\
\hline Journal of Bone \& Joint Surgery a & 1 & 30 & $\mathrm{~N}$ & NS \\
\hline Journal of Clinical Oncology ${ }^{f}$ & & 56 & $\mathrm{~N}$ & $\mathrm{Y}$ \\
\hline Journal of Clinical Ultrasound & 1 & 55 & $\mathrm{~N}$ & $\mathrm{Y}$ \\
\hline Journal of Computed Assisted Tomography ab & 2 & 36 & $\mathrm{~N}$ & $\mathrm{~N}$ \\
\hline Journal of Diagnostic Medical Sonography ${ }^{c}$ & 2 & 30 & $\mathrm{~N}$ & $\mathrm{Y}$ \\
\hline Journal of Digital Imaging & 1 & 33 & $\mathrm{~N}$ & $\mathrm{Y}$ \\
\hline Journal of Medical Imaging and Radiation Oncology (Australasian Radiology) & 6 & 100 & $\mathrm{~N}$ & $\mathrm{Y}$ \\
\hline Journal of Medical Imaging and Radiation Sciences (Canadian Journal of Medical Radiation & 2 & 34 & $\mathrm{~N}$ & Y \\
\hline Journal of Medical Radiation Science ${ }^{\mathrm{h}}$ (The Radiographer and Shadows) & 13 & 180 & $\mathrm{Y}$ & $\mathrm{NL}$ \\
\hline Journal of Neurosurgery & 1 & 26 & $\mathrm{~N}$ & NS \\
\hline Journal of Nuclear Cardiology & 1 & 36 & $\mathrm{~N}$ & Y \\
\hline Journal of Nuclear Medicine $a b$ & 7 & 52 & $\mathrm{~N}$ & NS \\
\hline Journal of Nuclear Medicine Technology c & 7 & 42 & $\mathrm{~N}$ & NS \\
\hline
\end{tabular}




\begin{tabular}{|c|c|c|c|c|}
\hline Journal of Radiotherapy in Practice & 2 & 35 & $\mathrm{~N}$ & $\mathrm{Y}$ \\
\hline Journal of Ultrasound in Medicine & 3 & 37 & $\mathrm{~N}$ & NS \\
\hline Journal for Vascular Ultrasound & 3 & 21 & $\mathrm{~N}$ & NS \\
\hline Lancet, The & 1 & 70 & $\mathrm{~N}$ & $\mathrm{Y}$ \\
\hline Magnetic Resonance Imaging Clinics of North America & 1 & 34 & $\mathrm{~N}$ & $\mathrm{Y}$ \\
\hline Magnetic Resonance in Medicine & 1 & 28 & $\mathrm{~N}$ & $\mathrm{Y}$ \\
\hline Management Today & 1 & 15 & $\mathrm{~N}$ & NS \\
\hline Medical Dosimetry & 2 & 38 & $\mathrm{~N}$ & $\mathrm{Y}$ \\
\hline Medical Education & 2 & 28 & $\mathrm{~N}$ & $\mathrm{Y}$ \\
\hline Medical Journal of Australia & 2 & 73 & $\mathrm{~N}$ & $\mathrm{Y}$ \\
\hline Medical Physics & 2 & 37 & $\mathrm{~N}$ & NS \\
\hline Medical Teacher & 2 & 18 & $\mathrm{~N}$ & $\mathrm{Y}$ \\
\hline New England Journal of Medicine a & & 56 & $\mathrm{~N}$ & NS \\
\hline Neurolmage & 1 & 16 & $\mathrm{~N}$ & $\mathrm{Y}$ \\
\hline Neuroimaging Clinics of North America & 1 & 19 & $\mathrm{~N}$ & $\mathrm{Y}$ \\
\hline Neuropsychologia & 1 & 14 & $\mathrm{~N}$ & $Y$ \\
\hline Neuroradiology ${ }^{b}$ & & 34 & $\mathrm{~N}$ & $\mathrm{Y}$ \\
\hline Neurosurgery & 1 & 19 & $\mathrm{~N}$ & $\mathrm{~N}$ \\
\hline Nuclear Medicine and Biology & 1 & 24 & $\mathrm{~N}$ & $\mathrm{Y}$ \\
\hline Nuclear Medicine Communications & 2 & 29 & $\mathrm{~N}$ & $\mathrm{~N}$ \\
\hline Nurse Educator & 1 & 23 & $\mathrm{~N}$ & $\mathrm{~N}$ \\
\hline Obstetric \& Gynecology Clinics of North America & 1 & 22 & $\mathrm{~N}$ & $\mathrm{Y}$ \\
\hline Oncology e & 3 & 41 & $\mathrm{~N}$ & $\mathrm{Y}$ \\
\hline Patient education and counselling & 1 & 20 & $\mathrm{~N}$ & Y \\
\hline Pediatric Radiology ${ }^{f}$ & & 33 & $\mathrm{~N}$ & $\mathrm{Y}$ \\
\hline Physics in Medicine \& Biology & 1 & 30 & $\mathrm{~N}$ & $\mathrm{Y}$ \\
\hline Radiation Therapist ${ }^{\prime}$ not listed BY RoMEO & & 29 & $\mathrm{~N}$ & $\mathrm{NL}$ \\
\hline RadioGraphics & 3 & 51 & $\mathrm{~N}$ & NS \\
\hline Radiography & 10 & 77 & $\mathrm{~N}$ & $\mathrm{Y}$ \\
\hline Radiologic Clinics of North America ${ }^{d}$ & 1 & 69 & $\mathrm{~N}$ & $\mathrm{Y}$ \\
\hline Radiologic Technology ac & 5 & 33 & $\mathrm{~N}$ & NS \\
\hline Radiology abd & 9 & 79 & $\mathrm{~N}$ & NS \\
\hline Radiotherapy \& Oncology & 6 & 53 & $\mathrm{~N}$ & $\mathrm{Y}$ \\
\hline RöFo b & & 12 & $\mathrm{~N}$ & NS \\
\hline Seminars in Nuclear Medicine & 4 & 47 & $\mathrm{~N}$ & $Y$ \\
\hline Seminars in Radiation Oncology & 1 & 32 & $\mathrm{~N}$ & $\mathrm{Y}$ \\
\hline Seminars in Ultrasound, CT \& MRI & 3 & 44 & $\mathrm{~N}$ & $\mathrm{Y}$ \\
\hline Soundeffects (ASA) & 4 & 46 & $\mathrm{~N}$ & $\mathrm{NL}$ \\
\hline Strahlentherapie und Onkologie & 1 & 15 & $\mathrm{~N}$ & $Y$ \\
\hline Surgical Clinics of North America & 1 & 20 & $\mathrm{~N}$ & 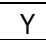 \\
\hline Ultrasonic Imaging $\mathrm{d}$ & & 20 & $\mathrm{~N}$ & $\mathrm{~N}$ \\
\hline Ultrasound in Medicine \& Biology & 3 & 25 & $\mathrm{~N}$ & $\mathrm{Y}$ \\
\hline Ultrasound in Obstetrics and Gynecology & 4 & 35 & $\mathrm{~N}$ & $\mathrm{Y}$ \\
\hline Year Book of Nuclear Medicine & 2 & 35 & $\mathrm{~N}$ & $Y$ \\
\hline \multicolumn{5}{|c|}{$\begin{array}{l}\text { Journal title in bold identified as a core journal in the following studies: a Burnham, }{ }^{13} \mathrm{~b} C h e w,{ }^{15} \mathrm{cHill} \text { et al. }{ }^{16} \text {, dHill et al.., }{ }^{23} \text { e Walcott }{ }^{14} \\
\text { f Journal title identified in pilot testing of questionnaire and added to list of journals } \\
.9 \text { Journal title added due to similarity in title name Breast and Breast Journal. Breast identified as read by interview participant R1P3. } \\
\text { h At the time of data collection, previous title The Radiographer was not open access } \\
\text { NL indicates this journal title was not listed in SHERPA / RoMEO } \\
\text { NS indicates that there was no statement in SHERPA / RoMEO regarding open access articles for this journal }\end{array}$} \\
\hline
\end{tabular}

The relationship between five factors and number of journals respondents MIWs could access is displayed in Table 3. Respondents employed in universities report access to a higher number of journals compared to those in clinical healthcare settings. Twenty-nine percent of the MIWs in clinical healthcare settings $(n=284)$ reported having access to one $(19 \%, n=54)$ or none $(10 \%, n=28)$ of the 94 listed journals. A statistically significant difference in number of journals that respondents could access was also observed across different types of clinical healthcare settings. For example, public sector medical imaging employees reported access to a higher number of journals than their colleagues in the private sector with $34 \%$ of private sector respondents $(n=130)$ indicating they had access to one $(22 \%, n=29)$ or none $(12 \%, n=15)$ of the journals. Also $42 \%$ MIWs in non- 
teaching hospitals and $40 \%$ in clinics reported access to one $(28 \%, n=12 ; 28 \%, n=22)$ or none $(14 \%, n=6 ; 12 \%, n=9)$ of the listed journals, respectively.

Table 3. Relationship between Five Factors and Number of Journals from List ( $N=94)$ That MIWS Could Access In Their Workplace

\begin{tabular}{|c|c|c|c|}
\hline Factor & Median Number (IQR) & Test of Difference & $P$ value \\
\hline $\begin{array}{l}\text { Work Setting } \\
\text { University } \\
\text { Clinical healthcare setting }\end{array}$ & $\begin{array}{c}23(60) \\
4(8)\end{array}$ & -6.033 a & $p<.001$ \\
\hline $\begin{array}{l}\text { Clinical healthcare setting } \\
\text { Health Sector } \\
\text { Public } \\
\text { Private } \\
\end{array}$ & $\begin{array}{l}5(11) \\
3(5)\end{array}$ & $-3.258^{a}$ & $p<.001$ \\
\hline $\begin{array}{l}\text { Clinical healthcare setting } \\
\text { Geographic location } \\
\text { Metropolitan } \\
\text { Regional } \\
\text { Rural or remote } \\
\end{array}$ & $\begin{array}{l}4(11) \\
3(6) \\
2(4)\end{array}$ & $7.343^{b}$ & $p=.025$ \\
\hline $\begin{array}{l}\text { Clinical healthcare setting } \\
\text { Workplace type } \\
\text { Teaching hospital } \\
\text { Non-teaching hospital } \\
\text { Clinic }\end{array}$ & $\begin{array}{l}5(9) \\
3(5) \\
2(4)\end{array}$ & $19.950^{b}$ & $p<.001$ \\
\hline $\begin{array}{l}\text { Clinical healthcare setting } \\
\text { Area of Specialization } \\
\text { Nuclear medicine } \\
\text { Radiography } \\
\text { Radiation therapy } \\
\text { Sonography }\end{array}$ & $\begin{array}{l}4(10) \\
3(6) \\
6(11) \\
4(5)\end{array}$ & $9.491^{b}$ & $p=.023$ \\
\hline
\end{tabular}

Table 4 presents the relationship between five factors and effective access to print and electronic journals in the workplace of MIWs. In relation to work setting, effective access to electronic journals was lower in clinical healthcare settings, with $25 \%(n=78)$ rating their workplace access to electronic journals as not easy $(12 \%)$ or no access $(13 \%)$ compared to $0 \%(n=0)$ universities. Similarly, effective access to print journals was lower in the clinical environment, with $29 \%(n=90)$ rating their access to print journals as not easy $(20 \%)$ or no access $(9 \%)$ compared to $4 \%(n=1)$ in universities. Apart from geographic location, statistically significant difference in effective access to journals was observed across clinical healthcare settings. Thirty-three percent $(n=47)$ in the private sector rated their workplace access to electronic journals as not easy (13\%) or no access (20\%) compared to $18 \%$ $(n=30)$ in the public sector $(11 \%, 7 \%)$. Similarly, for print journals $35 \%(n=50)$ private sector respondents rated their access as not easy $(24 \%)$ or no access $(11 \%)$ compared to $24 \%(n=40)$ in the public sector $(18 \%, 6 \%)$. In relation to workplace type, over $40 \%$ of MIWs in non-teaching hospitals and clinics rated their workplace access to electronic journals as not easy (14\%, 16\%) or no access $(27 \%, 24 \%)$, respectively compared to $14 \%(11 \%, 3 \%)$ in teaching hospitals. Area of specialization of the health professional also was associated with difference in effective access to journals in the workplace. MIWs specializing in radiography reported the lowest effective access, with $27 \%(n=43)$ rating their workplace access to electronic journals as not easy $(13 \%)$ or no access (14\%). 
Table 4. Relationship between Five Factors and Effective Access to Electronic and Print Journals in the Workplace of MIWs

\begin{tabular}{|c|c|c|c|}
\hline Factor & Journal format & Test of Difference & $P$ value \\
\hline $\begin{array}{l}\text { Work Setting } \\
\text { University } \\
\text { Clinical health care setting }\end{array}$ & $\begin{array}{l}\text { Electronic } \\
\text { Print }\end{array}$ & $\begin{array}{l}61.236 \text { a } \\
18.905 \text { a }\end{array}$ & $\begin{array}{l}p<.001 \\
p<.001\end{array}$ \\
\hline $\begin{array}{l}\text { Clinical healthcare setting } \\
\text { Health Sector } \\
\text { Public } \\
\text { Private } \\
\end{array}$ & $\begin{array}{l}\text { Electronic } \\
\text { Print }\end{array}$ & $\begin{array}{l}19.880^{c} \\
11.516^{c}\end{array}$ & $\begin{array}{l}p<.001 \\
p=.042\end{array}$ \\
\hline $\begin{array}{l}\text { Clinical healthcare setting } \\
\text { Geographic location } \\
\text { Metropolitan } \\
\text { Regional } \\
\text { Rural or remote }\end{array}$ & $\begin{array}{l}\text { Electronic } \\
\text { Print }\end{array}$ & $\begin{array}{l}10.967 \text { bNS } \\
14.284 \text { a† NS }\end{array}$ & $\begin{array}{l}p=.360 \\
p=.154\end{array}$ \\
\hline $\begin{array}{l}\text { Clinical healthcare setting } \\
\text { Workplace type } \\
\text { Teaching hospital } \\
\text { Non-teaching hospital } \\
\text { Clinic }\end{array}$ & $\begin{array}{l}\text { Electronic } \\
\text { Print }\end{array}$ & $\begin{array}{l}43.943^{b} \\
28.606^{a} \dagger\end{array}$ & $\begin{array}{l}p=.001 \\
p<.001\end{array}$ \\
\hline $\begin{array}{l}\text { Clinical healthcare setting } \\
\text { Area of Specialization } \\
\text { Nuclear medicine } \\
\text { Radiography } \\
\text { Radiation therapy } \\
\text { Sonography }\end{array}$ & $\begin{array}{l}\text { Electronic } \\
\text { Print }\end{array}$ & $\begin{array}{l}27.858 \text { a } \\
22.067 \text { a† NS }\end{array}$ & $\begin{array}{l}p=.015 \\
p=.092\end{array}$ \\
\hline
\end{tabular}

With regards to open access, only two of the reviewed 94 journals were listed as open access (Table 2, Column 4). Many of the journals offer the facility of open access articles (Table 2, Column 5). To discover what was available as open access articles, 2013-2014 issues for five journals were reviewed, with results presented in Table 5. Only a small percentage (0.7-19.5\%) of articles were available as open access.

Table 5. Number and Percent of Open Access Research and Evidence-Based Articles 2013-2014 for Five Journals

\begin{tabular}{|l|c|c|c|}
\hline & \multicolumn{2}{|c|}{$\begin{array}{c}\text { Articles that are original research, technical notes, } \\
\text { reviews and clinical guidelines 2013-2014 }\end{array}$} & $\begin{array}{c}\text { Total } \\
\text { Number }\end{array}$ \\
\hline Journal Title & $\begin{array}{c}\text { Open Access \& Full Text } \\
\text { Number }\end{array}$ & 407 & 0.7 \\
\hline Academic Radiology & 3 & 232 & 15.5 \\
\hline Cancer Treatment Reviews & 36 & 114 & 13.2 \\
\hline Radiography & 15 & 589 & 19.5 \\
\hline Radiotherapy \& Oncology & 115 & 529 & 3.0 \\
\hline Ultrasound in Medicine \& Biology & 16 & & \\
\hline
\end{tabular}

2. Does workplace accessibility to journals influence frequency of use?

Eighty-eight percent $(n=317)$ of MIWs report that they use journals to update their professional knowledge. Cross tabulations were performed to determine if workplace access was associated with frequency of use. Statistically significant results were observed for electronic and print journals (Table 6). For instance, 33\% of respondents who rated their ease of access to electronic journals as very easy $(n=92)$ read journals at least several times a week, compared to $7 \%$ who described their access as not easy $(n=38)$. 
Half of respondents who never read journals $(n=38)$ described their access to electronic journals as either not easy (16\%) or no access (33\%).

Table 6. Relationship between Effective Workplace Access of Tools and Frequency of Use in MIWs

\begin{tabular}{|c|c|c|c|c|c|c|}
\hline \multirow[t]{3}{*}{ Mediating Tool } & \multirow[t]{3}{*}{$\begin{array}{l}\text { Test of } \\
\text { Difference }\end{array}$} & \multirow[t]{3}{*}{$P$ value } & \multicolumn{4}{|c|}{$\begin{array}{l}\text { Difference in experience of MIWs at least several times a } \\
\text { month }\end{array}$} \\
\hline & & & \multicolumn{2}{|c|}{$\begin{array}{l}\text { Effective access to journals } \\
\text { "very easy" }\end{array}$} & \multicolumn{2}{|c|}{$\begin{array}{l}\text { Effective access to journals } \\
\text { "not easy" }\end{array}$} \\
\hline & & & $\%$ & $\mathrm{n}$ & $\%$ & $\mathrm{n}$ \\
\hline Electronic journals $(n=346)$ & $62.574 \dagger^{\mathrm{a}}$ & $p<.001$ & 33 & 92 & 7 & 38 \\
\hline Print journals ( $n=347$ ) & $67.618 \dagger^{a}$ & $p<.001$ & 34 & 53 & 5 & 65 \\
\hline \multicolumn{7}{|c|}{$\begin{array}{l}\text { a Monte Carlo method used for Fisher's exact test }(95 \% \mathrm{Cl}) 10000 \text { sampled tables with starting seed } 62438734 \\
\text { † Fisher's exact test }\end{array}$} \\
\hline
\end{tabular}

\section{DISCUSSION}

This study has extended knowledge on journals of relevance to MIWs. Of the 84 journals identified in this study as read by Australian MIWs, 68 were not previously identified as relevant journals for this allied health group ${ }^{13,16,23}$ (Table 2). This study established that for many MIWs, journals are not readily available in their workplace. Overall $27 \%(n=88)$ of respondents had access to just one or none of the listed journals, rising to $42 \%$ for employees in non-teaching hospitals. This means that a large proportion of MIWs do not have access to the tools that they need to update their professional knowledge and base their practice on current health information.

The findings from this study support and build upon the earlier work of McClusky, who reported that private sector allied health professionals had less access to journals than colleagues in the public sector. ${ }^{7}$ This study supports McClusky's finding and demonstrates that this differential access exists across both print and electronic journals for MIWs. ${ }^{7}$ As demonstrated in Tables 4 and 5, statistically significant difference in access to journals in the workplace of MIWs was shown to exist for the factors investigated. These are important findings. For example, in educational institutions, there is increased accessibility, physical and effective, to journals for MIWs. Translation of results from research undertaken where health professionals are given full access to university libraries such as Evans et al into clinical healthcare settings, where lower levels of access exist, needs to consider the issue of journal accessibility, so that learning outcomes and changes to professional practice are not compromised. ${ }^{24}$

Of particular importance for clinical healthcare settings is the impact that limited or no access to journals may have on patient care for MIWs. For instance, this research has established that MIWs employment in the private health sector is associated with lower physical and effective access to journals in the workplace. Forty-four per cent of hospitals in Australia operate in the private sector and account for 40\% (3.6 million) of all hospital admissions in Australia. ${ }^{25}$ The importance of this sector contributing toward positive health outcomes for Australia is apparent. However, the finding from this study that private sector employment of MIWs is negatively associated with access to journals suggests that the ability of these health professionals to utilise current discipline knowledge to improve patient care is compromised. In Australia, government provided electronic health information portals, such as Clinicians Health Channel and Clinicians Knowledge Network, provide health professionals with access to electronic journals and health and medical databases to support evidence based practice. ${ }^{26,27}$ However, these portals restrict access to those employed in the public sector. ${ }^{26,27}$ It would be timely for governments to review access restrictions so that all health professionals, regardless of their sector of employment, can access peer-reviewed evidence to support high quality health care.

While open access journals overcome access limitations their availability is currently limited. As shown in this study, only two of the 94 journals are listed as open access. This finding is in accord with Bail et al who identified that only $12 \%$ (27/224) of journals relevant to nursing had unrestricted open access. ${ }^{28}$ In addition, whilst many journals offer open access articles (Table 2), only a small percentage of published articles are currently available (Table 5). This indicates that open access journals and articles are unlikely to currently provide health professionals with the range of journal articles they need. Greater availability of open access journals for allied health professionals is needed. While open access journals for a given allied health professional group remain

(C) The Internet Journal of Allied Health Sciences and Practice, 2016 
limited, workplaces must continue to provide access to subscription-based journals so these professionals can base their practice on current, peer-reviewed evidence. In addition, to enhance access to currently available open access journals, workplaces must also address access limitation that health professionals experience accessing the Internet in their workplace. ${ }^{29}$

This current study also established that a statistically significant positive association exists between effective access to journals in the workplace and frequency of use in MIWs. As health professionals use information sources such as journals to modify and improve patient care reduced accessibility in the workplace constrains their ability to harness new knowledge disseminated through journals and apply it to practice. ${ }^{30,31}$ The implication is that by improving access to journals within workplaces, health professionals can continue to adopt current health information into their professional practice providing high quality current evidence-based patient care.

Access to information sources in the workplace is problematic for other health professions. For example, Gilmore et al identified that $21 \%$ of nurses working in medical wards were not satisfied with their workplace access to online health information. ${ }^{32}$ As noted previously, McClusky demonstrated that access to journals was more difficult for private sector occupational therapists. ${ }^{7}$ It is therefore important that each health profession investigate workplace accessibility of key information sources that underpin high-quality patient care.

\section{Limitations}

This study has several limitations. The first included the low survey response rate. However, the relatively large sample size $(\mathrm{N}=362)$ together with several indications suggests that survey participants were representative of the Australian population of MIWs. Some caution should however be exercised when interpreting the findings in relation to the broader Australian population of MIWs. It should also be acknowledged that MIWs may not be aware of what journals they can access in their workplace. If this is the case, then effectively, these journals are not accessible to the individual. It is recommended that workplaces review the journals that are available and ensure that staff are aware of and have access to relevant titles so that their professional practice can be based on the latest available evidence.

This study has examined a single Australian allied health profession, MIWs. Although problematic access to journals and online information sources in the workplace has been identified in occupational therapy and nursing, further research is needed with these and other health professional groups so that a more detailed understanding of workplace access to journals and its implications for quality healthcare is developed.., 31

\section{CONCLUSION}

Journals provide current, relevant health information and must be readily accessible in the workplace so that care of the patient is current with peer-reviewed evidence. The results of this research demonstrate that for many clinical MIWs, access to journals is currently limited with $42 \%$ percent of MIWs in non-teaching hospitals having access to none or only one professionally relevant journal. As only two of the examined journals are currently open access, and very few open access articles are currently available, it is unlikely that open access will provide MIWs with the range of journal articles they need to base their practice on current peer-reviewed evidence. It is recommended that workplaces review what journals are available to MIWs, make them known to staff, and also act to reduce the identified inequity of access that currently exists, so that regardless of where they are employed, MIWs can access professionally relevant journals and base their practice on current, peer-reviewed evidence.

\section{REFERENCES}

1. Thistlethwaite J, Spencer J. Professionalism in Medicine. Oxon, United Kingdom:Radcliffe Publishing Ltd; 2008.

2. Health and Care Professions Council. About registration. http://www.hcpc-uk.org/aboutregistration/standards/cpd/. Accessed 1 August, 2015.

3. Runciman WB, Hunt TD, Hannaford NA, et al. CareTrack: Assessing the appropropriateness of healthcare delivery in Australia. Med J Aust. 2012;197(2):100-5. [PMID 22794056]

4. Oermann MH, Nordstrom CK, Wilmes NA, et al. Information sources for developing the nursing literature. Int J Nursing Stud. 2008;45:580-7. [PMID 17145059]

5. Harding KE, Porter J, Horne-Thompson A, Donley E, Taylor NF. Not Enough Time or a Low Priority? Barriers to EvidenceBased Practice for Allied Health Clinicians. J Contin Educ Health Prof. 2014;34(4):224-31. [PMID 25530292]

6. Bawden D, Robinson K. Information behaviour in nursing specialities: a case study of midwifery. Journal of Information Science. 1997;23(6):407-21.

7. McClusky A. Occupational therapists report a low level of knowledge, skill and involvement in evidence-based practice. Australian Occupational Therapy Journal. 2003;50:3-12.

(C) The Internet Journal of Allied Health Sciences and Practice, 2016 
8. Melnyk BM, Fineout-Overholt E, Gallagher-Ford L, Kaplan L. The State of Evidence-Based Practice in US Nurses: Critical Implications for Nurse Leaders and Educators. J Nurs Adm. 2012;42(9):410-7. [PMID 22922750]

9. Cole J. The loop: Closing the physiotherapy information gap. Aust J Physiother 2001;47:83-5. [PMID 11552863]

10. Directory of Open Access Journals. 2014; http://doaj.org/. Accessed 9 December, 2014.

11. Allen M, Kaplan Jacobs S, Levy JR. Mapping the literature of nursing: 1996-2000. J Med Libr Assoc. 2006;94(2):206-20. [PMID 16636714]

12. Bohannon RW. Core Journals of Physiotherapy. Physiotherapy. 1999;85(6):317-21.

13. Burnham JF. Mapping the literature of radiologic technology. Bull Med Libr Assoc. 1997;85(3):289-92.[PMID 9285130]

14. Walcott BM. Mapping the literature of diagnostic medical sonography. Bull Med Libr Assoc. 1999;87(3):287-91. [PMID 10427429]

15. Chew FS. The scientific literature in Diagnostic Radiology for American readers: A survey and analysis of Journals, Papers, and Authors. Am J Roentgenol. 1986;147:1055-61. [PMID 3490145]

16. Hill DR, Gustave L, Levy JW. Brandon/Hill selected list of books and journals in allied health. Bull Med Libr Assoc. 1998;86(4):447-63. [PMID 9803286]

17. Australian Institute of Health and Welfare. Health and Community Services Labour Force 2006. Canberra: Australian Institute of Health and Welfare (AlHW), National Health Labour Force Series no. 42;2009.

18. Tashakkori A, Teddlie C. Integrating qualitative and quantitative approaches to research. In: Bickman L, Rog DJ, eds. The SAGE Handbook of Applied Social Research Methods. 2e. Thousand Oaks, California: SAGE Publications, Inc; 2009:283317.

19. Creswell JW, Plano Clark VL. Designing and Conducting Mixed Methods Research. Thousand Oaks: Sage Publications; 2007.

20. Mertens DM. Research Methods in Education and Psychology: Integrating Diversity with Quantitative and Qualitative Approaches. London: Sage Publications; 1998.

21. Fidel R, Green $M$. The many faces of accessibility: engineers' perception of information sources. Information Processing and Management. 2004:40:563-81.

22. Warner RM. Applied Statistics: From Bivariate Through Multivariate Techniques. Thousand Oaks, California: Sage Publications; 2008.

23. Hill DR, Stickell HN, Gustave L, Levy JW. Brandon/Hill selected list of print books and journals for small medical library. Bull Med Libr Assoc. 2001;89(2):131-53. [PMID 11337945]

24. Evans C, Yeung E, Markoulakis R, Guilcher S. An Online Community of Practice to Support Evidence-Based Physiotherapy Practice in Manual Therapy. J Contin Educ Health Prof. 2014;34(4):215-23. [PMID 25530291]

25. Australian Institute of Health and Welfare. Australian hospital statistics 2010-2012. Health services series no. 43. Cat. no. HSE 117. Canberra: AlHW;2012.

26. Hall G. Supporting health professionals in evidence-based practice: a case study of the Clinicians Knowledge Network. VALA 2008: 14th biennial conference and exhibition Melbourne Convention Centre Australia.

27. Westbrook JI, Gosling AS, Coiera E. Do clinicians use online evidence to support patient care? A study of 55,000 clinicians. J Am Med Inform Assoc. 2004;11(2):113-20. [PMID 14662801]

28. Bail K, Clarke R, Ranse J. Open access to nursing journals: an audit of the 2010 ERA journal list. Aust J Adv Nurs. 2013;30(4):5-11.

29. Shanahan M. Radiographers and the internet: An Australian perspective. Radiol Technol. 2010, 81(3): 223-32. [PMID 20051595]

30. O'Leary DF, Mhaolrunaigh SN. Information-seeking behaviour of nurses: where is information sought and what processes are followed? J Adv Nurs. 2011;68(2):379-90. [PMID 21707727]

31. Usher W. Developing policies for e-health: use of online health information by Australian health professionals and their patients. Health Information Management Journal. 2011;40(2):15-22. [PMID 21712557]

32. Gilmore JA, Scott SD, Huntington N. Nurses and Internet health information. J Adv Nurs. 2008;61:19-28. [PMID 21707727] 